\title{
Anti-Hemorrhoidal Medicinal Plants of the Department of Issia: Inventory and Cytotoxicity on HFF Cells of the Ethanolic Extract 70\% of Landolphia utilis A. Chev. (Apocynaceae)
}

\author{
Coulibaly Kiyinlma1 ${ }^{*}$, Etien Dibié Théodore², Orso Bosson Arobia Marie Bernadine ${ }^{1}$, Kanga Yao1, \\ Zirihi Guédé Noël² \\ ${ }^{1}$ Department of Plant Biology, UFR Sciences Biologiques, Université Peleforo Gon Coulibaly, Korhogo, Côte d'Ivoire \\ ${ }^{2}$ Botany Laboratory, UFR Biosciences, Félix Houphouët Boigny University of Cocody, Abidjan, Côte d'Ivoire \\ Email: ^kiyinlma@yahoo.fr
}

How to cite this paper: Kiyinlma, C., Théodore, E.D., Bernadine, O.B.A.M., Yao, K. and Noël, Z.G. (2019) Anti-Hemorrhoidal Medicinal Plants of the Department of Issia: Inventory and Cytotoxicity on HFF Cells of the Ethanolic Extract $70 \%$ of Landolphia utilis A. Chev. (Apocynaceae). Journal of Biosciences and Medicines, 7, 101110 .

https://doi.org/10.4236/jbm.2019.711009

Received: September 17, 2019

Accepted: November 8, 2019

Published: November 11, 2019

Copyright $\odot 2019$ by author(s) and Scientific Research Publishing Inc. This work is licensed under the Creative Commons Attribution International License (CC BY 4.0).

http://creativecommons.org/licenses/by/4.0/

\begin{abstract}
Objective: To identify the anti-hemorrhoidal medicinal plants of the Department of Issia and evaluate the cytotoxic activity of the most requested species. Methods: The plants used in hemorrhoid recipes in the Department of Issia (Côte d'Ivoire) were obtained using a semi-structured survey based on a questionnaire sheet. To assess the use of plants on the disease, Informant Consensus Factors (ICF) for each species were calculated. The harvested species were identified at the Centre National de Floristique (CNF) of the Félix Houphouët Boigny University (Côte d'Ivoire). Cytotoxicity tests were performed on HFF cells with the $70 \%$ ethanolic extract, prepared from the aqueous extract of the most cited species. Results: A total of twenty four medicinal species in eighteen families were recorded. Among these taxa are ten woody and fourteen herbaceous. Only three species gave an ICF greater than 0.5 . The ethanolic extract $70 \%$ of the frequently requested medicinal plant did not reveal any toxicity on HFF cells. Conclusion: These results revealed that the flora of the Department of Issia is rich in anti-hemorrhoidal medicinal plant species. Their use without side effects is revealed by the absence of toxicity in one of the most solicited plants.
\end{abstract}

\section{Keywords}

Hemorrhoids, ICF, Medicinal Plants, Tradipractitioners

\section{Introduction}

Plants play a very important role in the control of the vast majority of diseases. 
Herbal treatment is mainly facilitated by the fact that this practice is closely linked to customs and traditions [1]. According to the OMS, more than $80 \%$ of the world's population uses medicinal plants for treatment [2]. In recent years, the cost and availability of medicines and health benefits have become a constraint for populations. This is why traditional medicine appears to be an alternative in the resolution of health problems [3]. In the Department of Issia, several traditional health practitioners use medicinal plants to treat hemorrhoidal disorders, because surgical treatments are successful but remain very expensive and sometimes cause inconvenient side effects [4]. Indeed, hemorrhoidal pathologies are a venous dilation of the mucous membrane of the anus and rectum [5]. Mechanical factors such as relaxation of the musculo-ligamentary suspension system, alteration of the means of fixation of the hemorrhoidal plexus and vascular factors such as increased pressure at Thomson's pads, vascular anatomical changes, are responsible for the evolution of this pathology [6]. This hemorrhoidal disorder is the most frequent pathology of the terminal intestine, with a prevalence ranging from $4.4 \%$ to $86 \%$, causing discomfort in those suffering from it [7]. This condition affects both men and women, but men complain most about it [8]. To help our populations affected by this disease to benefit from the use of medicinal plants, we conducted an ethnobotanical survey on antihaemorrhoidal plants, and then evaluated the cytotoxicity of the taxon most solicited on HFF (Human Prepuce Fibroblasts) cells in vitro.

\section{Material and Methods}

\subsection{Study Environment}

The Department of Issia, an area of our ethnobotanical study, belongs to the Upper Sassandra region. It is located in the mid-western part of the average Côte d'Ivoire forest is between $6^{\circ} 25^{\prime}$ and $6^{\circ} 70^{\prime}$ north latitude, between $6^{\circ}$ and $7^{\circ}$ west longitude. This area is bordered to the north by the Departments of Daloa and Zoukougbeu, to the south by the Departments of Gagnoa and Soubré, to the west by the Departments of Buyo and Soubré and to the east by the Departments of Gagnoa and Sinfra. The surface area of the Department is $2613 \mathrm{~km}^{2}$. The relief is not very rugged, with a granitic dome near the city of Issia. The Department's hydrographic network includes, from west to east, rivers (Yoyo, Lobo, Goré, Bato, Daboro, Zozo, Grébo and Gongo) and multiple streams with more or less permanent flows.

\subsection{Plant Material}

The plant material consists of all the anti-hemorrhoidal plants collected during our ethnobotanical survey. For this study we were interested in the bark of Landolphia utilis because of its ICF.

\subsection{Cell Lines}

The cell support consists of human HFF (Human Foreskin Fibroblasts) cells. 
These are human cells that testify to the toxic activity of an extract. They have the particularity of forming a cellular mat after several days of culture (96 hours - 4 days), it is said that they are confluent, they stop dividing by contact inhibition. When these cells have been in culture for only 24 hours, they are in a state of mitosis (or dividing cells).

\subsection{Ethnobotanical Survey}

\subsubsection{Choice of Sub-Prefectures}

The choice of Sub-Prefectures was made on the basis of preliminary surveys of people who had previously suffered from hemorrhoidal disorders and who had found a cure through the traditional health practitioners of the Sub-Prefectures of the Department of Issia. Series of ethnobotanical surveys were carried out in three sub-prefectures, namely Nahio, Saioua and Iboguhé, in order to identify the different recipes used in the treatment of hemorrhoidal disorders. These semi-structured surveys were conducted using a surveysheet. The main lines of the interview concerned information on the plants used in hemorrhoidrecipes, the way in which these recipes are prepared and how they are administered. The method of approaching the populations was based on dialogue and using French and local languages (Bété, Baoulé). Access and interview in each of the three Sub-Prefectures was facilitated by an indigenous guide who also translated the local language into French.

\subsubsection{Methods of Identification}

Samples were collected in each of the Sub-Prefectures in situ thanks to the tradithérapeutes who made themselves available. These samples were stored in a herbarium. The identification was made with the data available in the literature but also in comparison with the herbarium of the National Center of Floristics (CNF) of the Biosciences U FR of the University Félix Houphouët Boigny (Côte d'Ivoire). In order to assess the informants' agreements on the use of plants against hemorrhoidal disorders, a factor (degree) of consensus of use or Informant Consensus Factor (ICF) was calculated according to the following formula:

$$
\mathrm{ICF}=\frac{N a}{N t}
$$

where $\mathrm{Na}$ is the number of informants who cited a species and $N t$ the total number of informants [9].

\section{Study of the Cytotoxicity of Landolphia utilis}

\subsection{Preparation of Plant Extracts}

After harvesting, the Landolphia utilis bark was cleaned of impurities, dried in the shade and in an air-conditioned laboratory for a week and then sprayed with an electric grinder. The fine powders obtained were stored in glass jars to prevent mould growth. 


\subsection{Aqueous Total Extract (ATE)}

The dried bark of Landolphia utilis was pulverized by an electric mill of the Moulinex type. The powder obtained was used to prepare the various extracts. Thus ATE was obtained according to the following method [10]: One hundred grams of plant powder are extracted in distilled water (1 litre) by grinding in a blender three times three minutes at room temperature. The homogenate obtained is wrung out in a square of cloth and then filtered successively four times on hydrophilic cotton and then on Wattman paper $(3 \mathrm{~mm})$. The filtrate is evaporated at $50^{\circ} \mathrm{C}$ using a Venticell ${ }^{\circ}$ type oven. The dry evaporate obtained is the aqueous total extract (ATE).

\subsection{Ethanolic Extract 70\% (EE70\%)}

The ethanolic extract $70 \%$ comes from the aqueous total extract, according to the following method [10]: Ten grams (10 g) of ATE are dissolved in $100 \mathrm{ml}$ of a $70 \%$ ethanol solution and homogenised in a Blender. After settling in a separating funnel, the supernatant is collected, filtered on cotton to remove any residue and dried in an oven $\left(50^{\circ} \mathrm{C}\right)$. The powder obtained is ethanolic extract $70 \%$ (EE70\%).

\subsection{Cytotoxicity Test}

To measure the toxicity of the ethanol extract $70 \%$ Landolphia utilis, HFF (Human Foreskin Fibroblasts) cells were inoculated into 96-well plates (CellStar) at a rate of 3000 to 5000 cells per well in $100 \mathrm{Yl}$ of D10 medium. These cells are kept in culture for 24 hours (dividing cells). They were then exposed for 24 hours to different concentrations $(0-800 \mathrm{Yg} / \mathrm{ml})$ of plant extract solubilized in PBS buffer. This was done in triplicate. Viability was determined using 3-(4,5diméthylthiazol-2-yl)-2,5-diphenyl tetrazolium bromide (MTT). The tetrazolium ring it contains is reduced to formazan by mitochondrial succinate dehydrogenase from metabolically active cells, which precipitates and gives a violet colour. The amount of precipitate formed is proportional to the number of living cells. In each well, MTT is added at a concentration of $500 \mathrm{Yg} / \mathrm{ml}$ and incubated for 3 hours at $37^{\circ} \mathrm{C}$. Formazan crystals are solubilized in dimethylsulfoxide (DMSO) $10 \mathrm{mM}$. The optical density at $544 \mathrm{~nm}$ was measured using a Safir (Tecan) spectrophotometer; this absorbance measurement will determine the relative amount of living and metabolically active cells [11]. Viability rate $=($ Abs544 $\mathrm{nm}$ extracted/Abs544 nm control) $\times 100$.

\section{Results}

\subsection{Ethnobotanical Data}

A total of twenty six people were interviewed, including ten in the Nahio sub-prefecture, six in the Saioua sub-prefecture and ten in the Iboguhé sub-prefecture. These interviewees include four women and twenty two men. They were all adults aged 45 and over and all had at least 10 years' experience in the per- 
formance of their duties. All were able to recognize the disease and clinical signs.

\subsection{Floral Analysis}

A total of twenty four anti-haemorrhoidal medicinal species have been identified, including ten woody and fourteen herbaceous species. They are divided into twenty four genera belonging to eighteen families, the most represented of which is the Apocynaceae family. It is followed by the family Euphorbiaceae, Fabaceae and Asteraceae. In this study, the plants identified and their therapeutic indications are grouped in Table 1.

Table 1. Plants used in the preparation of antihaemorrhoidal recipes.

\begin{tabular}{|c|c|c|c|c|c|}
\hline Taxons & Families & Vernacular names & Part used & Preparation method & $\begin{array}{c}\text { Method of } \\
\text { administration }\end{array}$ \\
\hline Adenia lobata (Jacq.) Engl. & Passifloraceae & Aereama (Baoulé) & Fresh leaves & Crushing & Local application \\
\hline Aframomum maleguata K. Schum & Zingiberaceae & Alosso (Baoulé) & Seeds & Decoction & Oral route \\
\hline Ageratum conyzoides $\mathrm{L}$. & Asteraceae & Bonwo (Bété) & Whole plant & Crushed + vegetable oil & Suppository \\
\hline Allium cepa L. & Amaryllidaceae & Djaba (Baoulé) & Bulb & Crushing (crushing) & Local application \\
\hline Alstonia boonei De Wild & Apocynaceae & Kaahi (Bété) & Bark & Water maceration & Oral route \\
\hline Capsicum frustescens $\mathrm{L}$. & Solanaceae & Yebê (Bété) & Whole plant & Crushed + vegetable oil & Suppository \\
\hline Cassia alata L. Roxb. & Fabaceae & Digbragbo (bété) & Fresh root & Decoction & Oral route \\
\hline Elaeis guineensis Jacq. & Arecaceae & Fording (Bété) & Leaf & Calcination & Suppository \\
\hline Euphorbia hirta L. & Euphorbiaceae & Semayuehi(Bété) & Whole plant & Crushed + water & Oral route \\
\hline Ficus exasperata Vahl. & Moraceae & Gnagnohi (Bété) & Leaf & Decoction & Oral route \\
\hline Harungana madagascariensis Lam. & Hypericaceae & Gogorehi (Bété) & Stem bark & Decoction & Local application \\
\hline Irvingia gabonensis Aubry. Lec & Irvingiaceae & Suokohi (Bété) & Bark & Decoction & Seat bath \\
\hline Landolphia utilis A. Chev. & Apocynaceae & Zatelikpa (Bété) & Bark & Maceration & Oral route \\
\hline Microglossa pyrifolia Lam. & Asteraceae & $\begin{array}{l}\text { Poutougbokobiya } \\
\text { (Bété) }\end{array}$ & Fresh leaves & Crushed & Local application \\
\hline Musa paradisiaca $\mathrm{L}$. & Musaceae & Djibô (Bété) & Reject and fruit & Decoction & Oral route \\
\hline Nicotiana tabacum $\mathrm{L}$. & Solanaceae & Djêle (Bété) & Leaf & Maceration & Oral route \\
\hline Occimum gratissimum $\mathrm{L}$. & Lamiaceae & Minikolou (Bété) & Whole plant & Crushed + vegetable oil & Suppository \\
\hline Paullinia pinnata L. & Sapindaceae & Siaguhebro (Bété) & Whole plant & Decoction & Oral route \\
\hline Picralima nitida Stapf. & Apocynaceae & Kakmou (Baoulé) & Fruit & Decoction & Oral route \\
\hline Piper guineense Schum and Thonn. & Piperaceae & Gnalikpa (Bété) & Leaf & Calcination & Suppository \\
\hline Piptadeniastrum africanum Hook. & Fabaceae & Galuhi (Bété) & Bark & Decoction & Oral route \\
\hline Pycnanthus angolensis Welw. & Myristicaceae & Duduhi (Bété) & Bark & Decoction & Seat bath \\
\hline Ricinodendron heudeloii Bail. & Euphorbiaceae & Kohi (Bété) & Bark & Decoction & Oral route \\
\hline Sida acuta Burm. & Malvaceae & $\begin{array}{l}\text { Chekpak-tchura } \\
\text { (Baoule) }\end{array}$ & Leaf & Calcination & Suppository \\
\hline
\end{tabular}




\subsection{Characterization of Recipes}

Organs taken from the vegetative growth habit of plants for the preparation of medicinal recipes, bark and leaves are mainly used (30\%). They are followed by whole plants (20\%) (Figure 1). Decoction is the most common method of preparation (46\%). This is followed by organ crushing (30\%) (Figure 2). The oral route is the most common method of recipe administration used by traditional health practitioners (Figure 3). Consensus Usage Factors (ICF): The calculation of species consensus values found a strong consensus index in the Landolphia utilis species (1 ICF). Out of a total of twenty four plants, twenty one have an index that does not reach the average consensus value (0.5). Only three species revealed an ICF greater than 0.5 (Table 2).

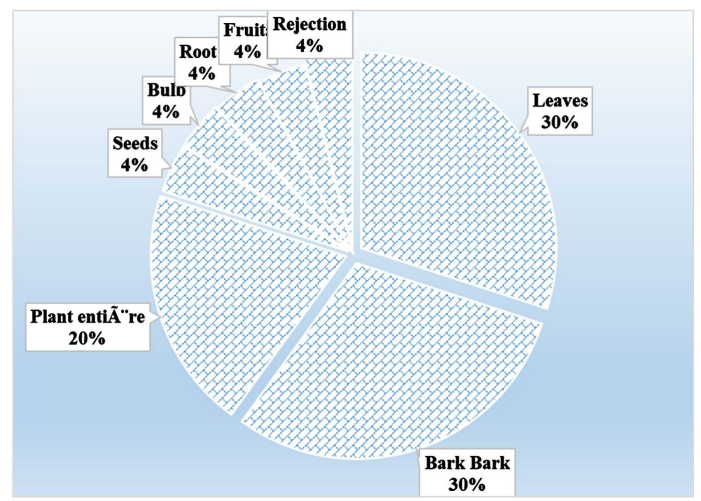

Figure 1. Used parts of the plants identified.

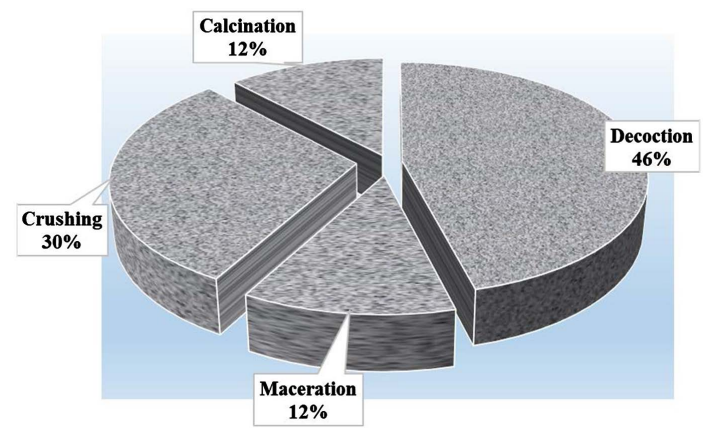

Figure 2. Method of preparing haemorrhoidal recipes.

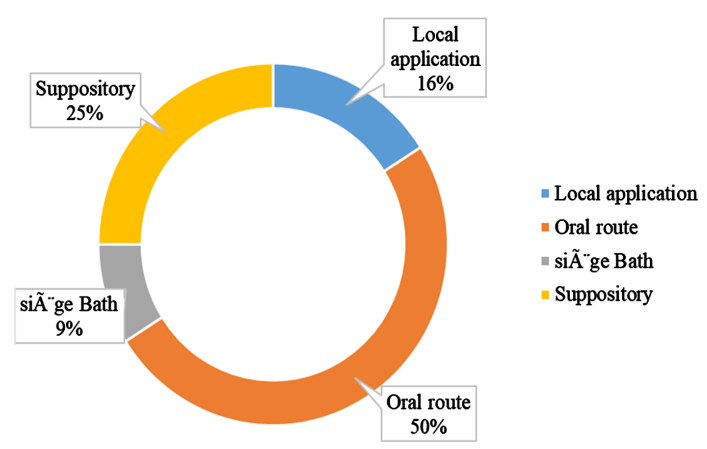

Figure 3. Method of administration of haemorrhoidal. recipes. 
Table 2. Informant Consensus Factors (ICF) for the species identified.

\begin{tabular}{|c|c|c|}
\hline Taxons & Families & ICF \\
\hline Adenia lobata (Jacq.) Engl. & Passifloraceae & 0.38 \\
\hline Aframomum maleguata K. Schum & Zingiberaceae & 0.19 \\
\hline Ageratum conyzoides L. & Asteraceae & 0.19 \\
\hline Allium cepa L. & Amaryllidaceae & 0.30 \\
\hline Alstonia boonei De Wild & Apocynaceae & 0.42 \\
\hline Capsicum frustescens $\mathrm{L}$. & Solanaceae & 0.26 \\
\hline Cassia alata L. Roxb. & Fabaceae & 0.46 \\
\hline Elaeis guineensis Jacq. & Arecaceae & 0.23 \\
\hline Euphorbia hirta L. & Euphorbiaceae & 0.38 \\
\hline Ficus exasperata Vahl. & Moraceae & 0.19 \\
\hline Harungana madagascariensis Lam. & Hypericaceae & 0.34 \\
\hline Irvingia gabonensis Aubry. Lec & Irvingiaceae & 0.38 \\
\hline Landolphia utilis A. Chev. & Apocynaceae & 1 \\
\hline Microglossa pyrifolia Lam. & Asteraceae & 0.46 \\
\hline Musa paradisiaca L. & Musaceae & 0.15 \\
\hline Nicotiana tabacum $\mathrm{L}$. & Solanaceae & 0.30 \\
\hline Occimum gratissimum $\mathrm{L}$. & Lamiaceae & 0.42 \\
\hline Paullinia pinnata L. & Sapindaceae & 0.26 \\
\hline Picralima nitida Stapf. & Apocynaceae & 0.5 \\
\hline Piper guineense Schum and Thonn. & Piperaceae & 0.57 \\
\hline Piptadeniastrum africanum Hook. & Fabaceae & 0.23 \\
\hline Pycnanthus angolensis Welw. & Myristicaceae & 0.30 \\
\hline Ricinodendron heudeloii Bail. & Euphorbiaceae & 0.46 \\
\hline Sida acuta Burm. & Malvaceae & 0.15 \\
\hline
\end{tabular}

\subsection{Toxicity of Ethanolic Extract 70\% Landolphia utilis on Human HFF Cells}

Observation of the effect of ethanolic extracts $70 \%$ L. utilis on cell viability shows that, whatever the conditions of the cells, the viability rate is always higher than $50 \%$. It can be concluded that $L$. utilis has no toxic effect on human cells (Figure 4). There is no significant difference between the averages according to the Turkey test at $5 \%$.

\section{Discussion}

This study was carried out in the Department of Issia, among twenty six traditional healers through an ethnobotanical survey. The traditional healers were all forty years of age or older. This is because knowledge of the uses of medicinal plants and their properties is generally acquired through long experience and 


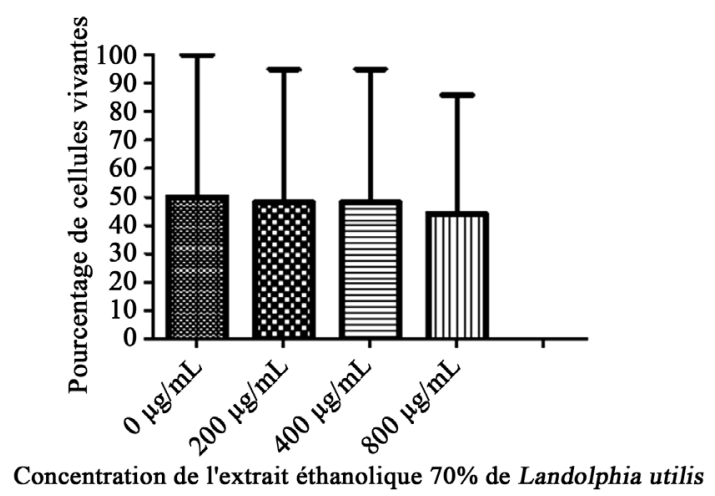

Figure 4. Dose response action of ethanol extract $70 \%$ of Landophia utilis on living HFF cells.

passed on from one generation to the next according to [12]. The results of this study showed that leaves and bark were the most commonly used organs (30\%). The interest in leaves and bark can be explained by the fact that they are the main site of biosynthesis and even the storage of secondary metabolites responsible for the biological properties of the plant [13]. To treat hemorrhoidal disorders, different methods of preparation and administration are used. Decoction was the most commonly used method of preparation (46\%). This method of preparation would collect the most active ingredients and would reduce or eliminate the toxic effect of certain recipes [14]. Decoction as the most widely used method of preparation has also been attested by the work of [15]. All of these 24 identified anti-hemorrhoidal plants have also been cited by several authors in Africa [9] [13] [16] [17] [18]. The values of the ICF of Landolphia utilis, Piper guineense and Picralima nitida found, are similar to those obtained by [9] who found many ICF with a value above 0.5 . The high ICF values of the plants show that these plants are potentially active and therefore could be of great interest in the treatment of hemorrhoidal disorders. The result of the cytotoxicity test performed on HFF cells showed that the ethanolic extract $70 \%$ of L. utilis is not toxic on human HFF cells, because according to [19], when the viability rate of an extract is strictly higher than $30 \%$ the extract is declared non-cytotoxic. Our results are consistent with those of [20] and [21] who also showed that the stem bark of Bersama Abyssinica (Fresen.) (Melianthaceae) and the leaves of Mallotus oppositifolius (Geiseler) Müller. Arg (Euphorbiaceae) used in the traditional environment in Côte d'Ivoire did not have cytotoxic effects on HFF cells.

\section{Conclusion}

Ethnobotanical surveys of traditional healers in the Department of Issia reveal that the Department's flora is rich in medicinal plant species capable of treating hemorrhoidal disorders. These plants would be of significant interest to modern medicine in order to overcome hemorrhoidal disorders. Therefore, the result of this cytotoxicity study encourages futures investigations of Landolphia utilis to 
isolate the molecule(s) responsible for anti-hemorrhoidal activity, in order to design a traditional improved drug (MTA) for the treatment of hemorrhoid.

\section{Acknowledgements}

We would like to thank the various traditional heath practitioners of the Issia Department for their sincere collaboration and the National Center for Floristics (CNF) of the Félix Houphouët Boigny University of Cocody Abidjan for the identification and confirmation of the names of the harvested plant species. The authors also thank the Laboratoire Adaptation et Pathogenénie des Microorganismes (LAPM) in Grenoble, France, where cytotoxicity studies were conducted.

\section{Conflicts of Interest}

The authors do not have any conflicts of interests regarding the publication of this paper.

\section{References}

[1] Binta, T. (2003) Phytochemical Study and Biological Activities of Trichilia emetica Vahl (Meliaceae). PhD Thesis in Pharmacy (Mali), 112 p.

[2] OMS (2004) OMS Strategy for Traditional Medicine for 2004-2023. Geneva, 78 p.

[3] Zerbo, P., Millogo, R.J., Nacoulma, O.G. and Van Damme, P. (2012) Medicinal Plants and Medical Practices in Burkina Faso: The Case of the Sanan. http://publication.lecames.org/index.php/pharm/article/view/13

[4] Shao, W.J. and Li, G.C. (2008) Systematic Review and Meta-Analysis of Randomized Controlled Trials Comparing Stapled Haemorrhoïdopexy with Conventional Haemorrhoidectomy. The British Journal of Surgery, 95, 147-160. https://doi.org/10.1002/bjs.6078

[5] Dal Monte, P.P., Tagariello, C., Sarago, M., Giordano, P., Shafi, A., Cudazzo, E., et al. (2007) Transanal Haemorrhoidal Dearterialisation: Nonexcisional Surgery for the Treatment of Haemorrhoidal Disease. Techniques in Coloproctology, 11, 333338. https://doi.org/10.1007/s10151-007-0376-4

[6] Miller, R., Bartolo, D.C., Roe, A., Cervero, F. and Mortensen, N.J. (1988) Anal Sensation and the Continence Mechanism. Diseases of the Colon \& Rectum, 31, 433 438. https://doi.org/10.1007/BF02552612

[7] Madoff, R.D. and Fleshman, J.W. (2004) American Gastroenterological Association Technical Review on the Diagnosis and Treatment of Hemorrhoids. Gastroenterology, 126, 1463-1473. https://doi.org/10.1053/j.gastro.2004.03.008

[8] Haas, P.A., Fox, J.R., Haas, G.P., et al. (1984) The Pathogenesis of Hemorrhoids. Diseases of the Colon \& Rectum, 27, 442-450. https://doi.org/10.1007/BF02555533

[9] Ilumbe, G.B., Van Damme, P., Lukoki, F.L., Joiris, V., Visser, M. and Lejoly, J. (2014) Contribution to the Study of Medicinal Plants in the Treatment of Hemorrhoids by Twa Pygmies and Their Neighbour Oto de Bikoro, DRC. Congo Sciences, 2, 46-54.

[10] Zirihi, G.N., Kra, A.M. and Guédé-Guina, F. (2003) Evaluation of the Antifungal Activity of Microglossa pyrifolia (Larmarck) O. kuntze (Asteraceae) "Pymi" on the in Vitro Growth of Candida albicans. Revue de Médecine et de Pharmacie, 17, 11-19.

[11] Mosman, T. (1983) Rapid Colorimetric Assay for Cellular Growth and Survival: 
Application to Proliferation and Cytotoxicity Assays. Journal of Immunological Methods, 65, 55-63. https://doi.org/10.1016/0022-1759(83)90303-4

[12] Klotoé, J.R., Dougnon, T.V., Koutouvo, K., Atègbo, J.M., Loko, F., Akoègninou, A., Aklikokou, K., Dramane, K. and Gbeassor, M. (2013) Ethnopharmacological Survey on Antihemorrhagic Medecinal Plants in South of Benin. European Journal of Medicinal Plants, 3, 40-51. https://doi.org/10.9734/EJMP/2013/2093

[13] Ngene, J.P., Ngoule, C.C., Kidik Pouka, C.M., Mvogo Ottou, P.B., Ndjib, R.C., Dibong, S.D. and Mpondo Mpondo, E. (2015) Importance in the Traditional Pharmacopoeia of Flavonoid Plants Sold in the Markets of Douala Est (Cameroon). Journal of Applied Biosciences, 88, 8194-8210. https://doi.org/10.4314/jab.v88i1.6

[14] Salhi, S., Fadli, M., Zidane, L. and Douira, A. (2010) Floral and Ethnobotanical Studies of Medicinal Plants in the City of Kenitra (Morocco). Lazaroa, 31, 133-146. https://doi.org/10.5209/rev_LAZA.2010.v31.9

[15] N'Guessan, K., Kadja, B., Zirihi, G.N., Traoré, D. and Ake-assi, L. (2009) Phytochemical Screening of Some Ivorian Medicinal Plants. Science \& Nature, 6, 1-15. https://doi.org/10.4314/scinat.v6i1.48575

[16] Mpondo Mpondo, E., Dibong, S.D., Ladoh, Y.C.F., Priso, R.J. and Ngoye, A. (2012) Phenol Plants Used by the Populations of Douala City. Journal of Animal and Plant Sciences, 15, 2083-2098.

[17] Dibong, S.D., Mpondo Mpondo, E., Ngoye, A. and Kwin, N.F. (2011) Medicinal Plants Used by the Bassa Populations of the Douala Region of Cameroon. International Journal of Biological and Chemical Sciences, 5, 1105-1117. https://doi.org/10.4314/ijbcs.v5i3.72227

[18] Yinyang, J., Mpondo Mpondo, E., Mchatat, M., Ndjib, R.C., Mvogo Ottou, P.B. and Dibong, S.D. (2014) Alkaloid Plants Used by the Populations of Douala City (Cameroon). Journal of Applied Biosciences, 78, 6600-6619. https://doi.org/10.4314/jab.v78i1.7

[19] Bené, K. (2017) Medicinal Plants of Gontougo (Zanzan District, Côte d'Ivoire): Inventory, Evaluation of the Pharmacological Activities of Two Plants and Formulation of a Dermatological Ointment Based on the Hydroalcoholic Extract of Bersama abyssinica Fresen. (Melianthaceae). Thèse de Unique de Botanique, Université Félix Houphouët-Boigny (Côte d'Ivoire), 200 p.

[20] Camara, D., Bené, K., Gnahoue, G., Fofié, N.B.Y. and Zirihi, G.N. (2016) Ethnobotanical Study, Evaluation of the Antifungal Activity on Candida albicans and Toxicity on HFF Cells of Bersama abyssinica (Fresen.), a Plant from the Ivorian Pharmacopoeia. European Scientific Journal, 12, 171-1885.

https://doi.org/10.19044/esj.2016.v12n3p171

[21] Yapo, Y.C.V., Konkon, G., Coulibaly, K., Camara, D. and Zirihi, G.N. (2016) Botanical Study, Evaluation of Antifungal Activity on the in Vitro Growth of Candida albicans and Toxicity on HFF Cells of Mallotus oppositifolius (Geiseler) Müller Leaves. Arg (Euphorbiaceae). Journal of Animal and Plant Sciences, 28, 4330-4339. 